\section{Queen Charlotte's Hospital}

The Department of Health announced last week that the present Queen Charlotte's Hospital and the Chelsea Hospital for Women will eventually be rebuilt as part of the new King Edward Memorial Hospital which is being developed on the site of St. Bernard's Hospital, Ealing. Queen Charlotte's name and functions will be preserved at the new site, which, says the Department, is well placed to serve the area from which Queen Charlotte's is increasingly drawing its patients. The new unit will provide the obstetrical and gynaecolog:cal services of the new district general hospital, and Queen Charlotte's links with posigraduate medical education through its associat:on with the Institute of Obstetrics and Gynaecology will continue after the move to Ealing.

Discussions will start soon between Sir Keith Joseph and the board of governors, the other hospital authorities concerned, the University Grants Committee, and the University of London to settle the general outline of the scheme. Since it will be about 10 years before Queen Charlotte's moves to its new home, improvements will be made to the existing buildings in order to maintain a high level of services to patients.

\section{Community Medicine}

The inaugural meeting of the combined faculty of community medicine of the Royal Colleges of Physicians of London and Edinburgh and the Royal College of Physicians and Surgeons of Glasgow is planned for March 1972. Doctors eligible for foundation membership of the faculty are invited to apply in an advertisement at p. li. See also letter from the presidents of the Royal Colleges, p. 117.

\section{People in the News}

Professor F. J. Gillingham, of Edinburgh University, left on 3 October to visit Yugoslavia at the invitation of the University of Ljubljana. He is to lecture to the clinical departments of neurosurgery and neurophysiology at the university and also in Belgrade, where he will be the guest of the neurosurgical clinic at the medical faculty of the university.

Professor Hugh Robson, vice chancellor of Sheffield University, has been appointed chairman of the Advisory Council on the Misuse of Drugs set up under the Misuse of Drugs Act 1971.

\section{COMING EVENTS}

Leeds and West Riding Medico-Legal Society. -Details and copies of the programme October-March, are obtainable from the legal secretary of the society, 1 Albion Street, Leeds LS1 SER. (Tel. Leeds 31534/5.)

British Society of Medical and Dental Hypnosis. -Details and copies of the programme, October -May, are obtainable from the secretary of the metropolitan branch, Mrs. M. Samuels, 10 Chillerton Road, London S.W.17 (Tel. 01-672 3025.)

Royal Postgraduate Medical School.-Seminar on "Cardiomyopathy" organized by the International Society of Cardiology, 14-16 October. Panel discussion on 16 October at 10 a.m. open to all doctors.

B.M.A. (Mid-Essex Division) and Chelmsford Medical Society,-Symposium on "Infections,"
23-24 October, Broomfield Hospital, Chelmsford. Details from the secretary, Medical Academic Unit, Chelmsford and Essex Hospital, London Road, Chelmsford CM2 $0 \mathrm{QH}$.

Society for Drug Research.-All day symposium, "Interferon Inducers," 27 October, Pharmaceutical Society, London W.C.1. Fee $£ 1.50$ (nonmembers). Applications to Dr. J. F. Cavalla, Wyeth and Brother Ltd., Huntercombe Lane South, Taplow, Maidenhead, Berks. (Tel. 01-75 28311.)

Interferon Inducers.-Symposium arranged 27 October by Society for Drug Research at the Pharmaceutical Society, 17 Bloomsbury Square, London W.C.1. Details from Dr. A. B. Simmonds, Chelsea College, Manresa Road, London S.W.3.

"Multiple Sclerosis."-One day symposium for general practitioners, 28 October, Wolverhampton, organized by the Royal College of General Practitioners and the Multiple Sclerosis Society. Registration fee $£ 1.50$. Applications to the general secretary, Multiple Sclerosis Society, 4 Tachbrook Street, London SWIV 1SJ. (Tel. 01-834 8231/2/3.)

"Occupational Health Services in Hospitals." All-day joint meeting of the R.S.M. Section of Occupational Medicine, the Society of Occupational Medicine, and the Royal College of Nursing, 28 October, at the R.S.M. Details and application forms are obtainable from the sections officer, Royal Society of Medicine, 1 Wimpole Street, London WIM 8AE. (Tel. 01580 2070.)

"Electroconvulsive Therapy."-One-day symposium, 29 October, Bath. Admission by ticket obtainable free from Miss Crossman, medical secretaries' office, Mendip Hospital, Wells, Somerset. (Tel. Wells 2211-3.)

Royal College of Surgeons of England.Advanced discussion group for consultarts and senior registrars, "Management of Raised Intracranial Pressure after Head Injury," 1 November, 6 p.m. Fee $£ 1$ (including buffet supper). Applications, by 27 October, to the secretary, R.C.S., Lincoln's Inn Fields, London WC2A 3PN. (Tel. 01-405 3474.)

\section{UNIVERSITIES AND COLLEGES}

LONDON

The title of professor of tumour pathology has been post at the Institute of Cancer Research, Royal Cancer lospital.

The title of professor of clinical neurology has been conferred on Dr. J. Marshall in respect of his post at the Institute of Neurology.

on Mr. J. H. W W yllie in respect of his post onferred versity. College Hospital Medical School. M.D. C.. D. Allen, E. G. Anderson, Judith M.
Chessells, J. D. Davies, J. F. Hallpike, Jane M. Semmens, R. O. Weller.

\section{SOCIETIES AND LECTURES}

For attending lectures marked a fee is charged made first to the institution concerned.

\section{Monday, 11 October}

Instrtutr of Dermatology.-4.30 p.m., Professor INSTITUTB OF : Dermatological Diagnosis. p.m., Combined staff consultation clinical meeting. Royal Postgraduate MEDicaI School. 4 p.m.;
Professor P. J. Lawther: Different Kinds of Smokes.

OYAL SOCIRTY OF MEDICTNE. -5.30 p.m., Library and Lay Section open meeting, Sir Dugald Baird, troi.

\section{Tuesday, 12 October}

RoYal ARMY Mrdical COLLEGr.-5 p.m., Sir Breast Cancer.
Tt. Bartholomew's Hospital.-5 p.m., Dr. L. E. Glvnn: Some

ST. jAMtis S HOSPITAL Road, London S.W.12, 12.30 p.m., Dr. S. Greer Attempted Suicide.

Wednesday, 13 October Royal COLLBge of SURGgons OF EDINBURGH.- 3
p.m., Professor T. Lehner: Immuno'ogical Aspects of Oral Ulceration.

XXFORD UNIVERSITY.-At Nuffield Maternity Home, Radcliffe Infirmary, 5 p.m., Professor L. G. Wel (North Carolina): Erythrocyte Transport Defects in Disease.

INSTrTuTB OF DISBases OF THE Chest.-5 p.m., Nature of Malignancy. INSTITUTE OF PSYCHIATRY. -5.30 p.m., Dr. W. Warren: Adolescent Psychiatry-Another Subspecialty?

INSTITUTB OF UROLOGY.-5 p.m., Mr. J. D. Fergusson: Management of Prostatic Malignancy. ROYAL COLLEGE OF OBSTETRICIANS AND GYNAB COLOGISTS.-5.30 p.m., postgraduate museum demonstration by Dr. C. W. Taylor: Mesodermal Mixed Tumours. 5.15 P.m. Chisholme (Montreal): Intestinal Factors in Insulin Secretion.

Royai Postgraduatr Medical School.-2 p.m., Dr. W. R. Cattell: Hypo- and Hypernatraemic States.

Thursday, 14 October

ABERDEEN UNIVERSITY. - At Foresterhill medical buildings, 5 p.m., Professor M. A. Epstein Viruses and Human Cancer.

CFrTR OB OBSTTRICS AND GYNAECOLOGY.-At Chelsea Hospital for Women, (1) 11.15 a.m Mension, Dr. G. I. M. Swyer: Management of Bishop. Insablems; (2) 2 p.m., Dr. P. M. F utism. (Admission by ticket only, obtainable from secretary, Institute of Obstetrics and Gvnaeco!ogy, Chelsea Hospital for Women, London S.W.3.)*

St. MARY's Hospital Medcal School. -5 15 p.m.,
Mrs. S. Kitzinger: Preparation for Childbirth.

\section{Friday, 15 October} Charles Burns Clinic, Brrmingham.-At Queens-
bridge Road, Moseley, 4 p.m., Mr. P. Widlake: Educational Priority Areas-Some Conclusions. INSTITUTE OF LARYNGOLOGY AND OTOLOGY. -4.30 p.m., Mr. C. Butler: Treatment of Tumours of the Salivary Gland.

INSTITUTB OF OBSTBTRICS AND GyNABCOLOGY.-A Queen Charlotte's Hospital, 3 p.m., discussion, Mr. H. G. E. Arthure, Mr. M. Dunstan Maternal Mortality. (Admission by ticket only, and Gynaecology, Chelsea Hospital for Women, London S.W.3.)* Royal CollbGB of Genkral Practitioners: ScotTish Councri.-At Glasoow University department of mechanical engineering. 5.15 p.m. Allen and Margaret Wilson memorial lecture by Dr. H. F. V. Riddle: Incidence of Allergic Alveolitis and Respiratory Illness in Malt Workers. Mr. W. Gillison: A Fresh Look at Oesophagitis.

\section{CORRECTIONS}

Interpretation of Arteriography

In the letter from Dr. James Bull on this subject (2 October, p. 47) a printing error occurred in the reference, which should read as follows: Newton, T. H., and Couch, R. S. C., Radiology, $1960,75,766$

\section{Tay-Sachs Genotypes}

In the article "Prenatal Diagnosis of Tay-Sachs Genotypes" by Drs. Ruth Navon and Baruch Padeh (2 October, p. 17), the fourth line of the penultimate paragraph under the heading "Patients and Methods" should have read "The electrode buffer was $0.04 \mathrm{M}$ citrate phosphate pH 6.0."

\section{Notice to Author:}

When original articles and letters for publication are not submitted exclusively to the British Medical fournal this must be stated.

Correspondence on editorial business should be addressed to the Editor, British Medical fournal, B.M.A. House, Tavistock Square, London WC1H 9JR. Telephone: 01-387 4499. Telegrams : Aitiology, London, W.C.1.

Authors wanting reprints of their articles should notify the Publishing Manager, B.M.A. House, Tavistock Square, WCIH 9JR, on receipt of proofs. 